\title{
Beneficial Effects of Pyridoxal Phosphate on Hydrogen Peroxide Induced Stress on Isolated Pancreatic Acinar Cells
}

\author{
Rajanna Ajumeera and Vijayalakshmi Venkatesan * \\ Dept of Biochemistry/Stem Cell Research, National Institute of Nutrition (ICMR), Jamai Osmania, Tarnaka, \\ Hyderabad, India \\ * Correspondence: v.venkateshan@gmail.com; \\ Fax Number: +91-40-27019074; Telephone number: + 91-40-27197301
}

\begin{abstract}
Aims: To study the effects of pyridoxal phosphate (PLP) on oxidative stress in isolated pancreatic acinar cells. We have previously shown that PLP has cytoprotective and insulinotropic effects on mice islet cells in vivo and in vitro studies. Main methods: Acinar cells were isolated from three months old WNIN male rats and were cultured in vitro for a period of $24 \mathrm{~h}$ in $\mathrm{CO}_{2}$ incubator. Later the cells were divided into four groups as untreated (group 1), $\mathrm{H}_{2} \mathrm{O}_{2}$ treatment (group 2), PLP treatment (group 3) and PLP followed by $\mathrm{H}_{2} \mathrm{O}_{2}$ treatment (group 4). Cell viability was confirmed using MTT assays, oxidative stress levels were measured with ROS assay, change in different protein levels were recorded by flow cytometry. The acinar cells insulin secretion assay was performed with ELISA. The amylase protein expression was assessed using confocal microscopy. Key findings: The cell viability of acinar cell in group 1 was considered as $100 \%$, while in group 2 it was reduced to $82 \%$ due to $\mathrm{H}_{2} \mathrm{O}_{2}$ effect, and in group $3(99.8 \%)$ and group $4(99.5 \%)$ were near to group 1 due to the cytoprotective effect of PLP. The ROS levels were increased by 1.47 folds in group 2, while PLP decreased to 1.02 fold in group 4, which was comparable with the changes in group 1. Beneficial effects of PLP were also observed from the increased expression levels of acinar cells are amylase -2.01, neurogenin-3-9.51, PDX-1- 23.6 and insulin-13.5 in group 3 compared to group 1. The specificity of PLP's response was confirmed by amino oxy acetic acid (AOAA), a specific PLP inhibitor. The increased amylase protein localization with PLP was confirmed by confocal microscopy. Insulin secretion efficiency of acinar cells was observed to be 6.13 folds higher at basal and 24.63 fold higher at stimulated levels in group3 compared to group1. Significance: Our results advocate the antioxidant and cytoprotective effects of PLP on the pancreatic acinar cell along with increased pancreatic marker expressions of amylase,PDX-1, neurogenin-3 and insulin proteins.
\end{abstract}

Keywords: acinar cells; PLP; amylase; insulin secretion; FACS; viability; PDX-1

\section{Introduction}

Reactive oxygen species (ROS) generated in healthy or diseased cells is degraded through protective antioxidant machinery; consequently it leads to oxidative stress (OS). Which is believed to play an important role in the mediation of cell injury, DNA damage, oxidation of amino acids, lipid peroxidation, protein-protein cross talk were leads loss of its functions due to poor defence system of the organ [1]. Other side reactive oxygen species (ROS) is not only a toxic cellular metabolic product that is frequently associated with disease conditions, but it may be act as critical intermediate stage of cellular signalling pathways [2]. Several agents are responsible for generation of oxidative stress. One such recognized and popular agent is hydrogen peroxide $\left(\mathrm{H}_{2} \mathrm{O}_{2}\right)$, which results in DNA damage, decreased in protein and lipid levels of cell [3] through increasing intracellular ROS levels [4] leads to cellular damage [5,6]and other complications. 
Pancreatic tissue is highly susceptible to oxidative damage compared to all other organs in the body, due to a weak anti-oxidant defence system [7]. The elevated levels of oxidative stress were showed to cause beta cell dysfunctions due to an impaired insulin secretion. In recent times there has been a great interest to explore alternative strategies to improve glycemic control in diabetes by preventing/rescuing the islets from beta-cell death and damage due to high oxidative stress [8]. The promises of antioxidants like Vitamin C [9,10], Vitamin E [11], N-acetyl-L-cysteine [12], epictechin [13] and curcumin [14] were to ameliorate the free radical effects have been well documented both in vitro and in vivo model systems of diabetes [15] to some extent in human subjects [16]. Working in this direction, our previous work from our lab investigated the cytoprotective and insulinotrophic effects of PLP (coenzyme form of Vitamin B6) against STZinduced beta-cell dysfunction, advocating its potent anti-oxidative functions [17]. Further, the efficacy of Vitamin B6 against ROS-related toxicity has been shown in plant model systems was in the order of pyridoxal > pyridoxine> pyridoxamine [18].

Pancreatic tissues possess a surprising capacity of regeneration. Bonner-Weir and coworkers studied pancreatectomy in rats as a model for diabetes and demonstrated that within 8-10 weeks following 90\% removal of the pancreas there was considerable regeneration of both functional exocrine and endocrine tissue $[19,20]$. Pancreatic exocrine cells were expressed of insulinproducing $\beta$ cells by expressing PDX1, NGN3, and MAFA Genes [21-23]. However, pancreatic acinar cells were convert into ductal cells and direct evidence for acinar-to-ductal transdifferentiation was provided both in vitro [24, 25] and in vivo [26, 27]. Cell lineage tracing experiments were revealed the origin of the newly made insulin-secreting cells from pancreatic acinar cells [25,28]. Our present work have focused on isolation of acinar cells and assessment of cell integrity, viability and cyto-protectivity of PLP along with its key regulatory proteins of pancreas against $\mathrm{H}_{2} \mathrm{O}_{2}$ induced stress in acinar cells.

\section{Material and Methods}

\section{Animals}

This study was approved by the Institutional Animal Ethical Committee (IAEC Committee, NCLAS, NIN (ICMR), Hyderabad/Committee for the Purpose of Control and Supervision of Experiments on Animals (CPCSEA) (Regd. No. 154/1999/CPCSEA) and experiments were carried out as per the animal ethical norms. Three months old male WNIN rats were collected from the colony, housed in cages, fed on regular rat chow and maintained under optimal ambience of temperature, light (12 hour dark/light cycles), oxygen, humidity and ventilation till sacrifice. All studies were performed under identical conditions. Animals were subjected to a $16 \mathrm{~h}$ fasting prior to euthenization to normalize for the differences in feeding patterns.

\section{Reagents and antibodies}

Primary antibodies, amylase (H-300, SC-25562), Insulin (H-86, SC-9168), Cytokeratin-19 (M-17, Sc33111), Vimentin (H-84, SC-5565), PDX-1(N-18, SC-14662) and secondary antibodies - goat antirabbit IgG-FITC (SC-2012), goat anti-mouse IgG-Texas Red (SC-2781) and donkey anti goat IgGTexas Red (SC-2783) and neurogenin-3 (M-80, SC-25655) were obtained from Santacruz Biotechnology, California for FACS analysis. Chemicals and reagents such as collagenase II from clostridium histolyticum (C-6885, Sigma), Trypsin EDTA solution (T4049, sigma), NaCl (Product Number-15915, Qualigens,Mumbai), KCl (Product number-22205, Qualigens, Mumbai), $\mathrm{CaCl}_{2}$ (Qualigens, Mumbai, India) $\mathrm{MgCl}_{2}$ (Product number-15535, Qualigens, Mumbai, India) Hepes (H3375, Sigma Life sciences, USA), D-Glucose (Product number- 15405, Qualigens, Mumbai), Albumin Bovine serum Fraction-V (A-3059, Sigma, USA), $\mathrm{KH}_{2} \mathrm{PO}_{4}$ (Product number- 13405, Qualigens, Mumbai), non essential amino acid (M 7145, Sigma), Trypsin Inhibitor Soyabean (K-213, AMERCO, Ohio) were procured as mentioned in parentheses. 


\section{PLP and $\mathrm{H}_{2} \mathrm{O}_{2}$ treatments}

PLP concentrations for the study were optimized from 0.5, 1, 2.5, 5 and $10 \mathrm{mM}$ and based on maximum amylase protein expression; we have subsequently used $5 \mathrm{mM}$ PLP for all the experimental groups. We have used $100 \mu \mathrm{M}$ concentration of $\mathrm{H}_{2} \mathrm{O}_{2}$ [29] as reported in astrocytes cells.

\section{Isolation and Maintenance of Primary cultures of Acinar cells}

Acinar cells isolation protocol has been similar to the method [30], with minor modifications. Briefly, soon after dissection of the pancreas, around 350-400 mg tissue was collected in plain RPMI medium with $1 \mathrm{X}$ pencillin-streptomycin antibiotic. The tissue was minced into small pieces, washed and re-suspended in isolation buffer $(1 \mathrm{mg} / \mathrm{mL}$ collagenase type II (sigma) and $0.1 \%$ Trypsin EDTA

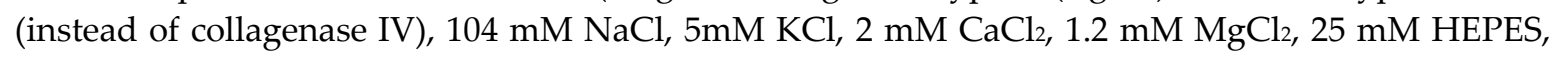
$2.5 \mathrm{mM}$ D-Glucose, $0.1 \%$ BSA, $1 \mathrm{mM} \mathrm{NaH}_{2} \mathrm{PO}_{4}, 0.01 \%$ non essential amino acid and $0.01 \%$ soyabean trypsin inhibitor adjusted to $\mathrm{pH}$ 7.4) and incubated for 15 minutes at room temperature at speed of 40 isnt it too less rpm for 15 minutes. After repeated washings and centrifugations, the obtained acinar enriched fraction with very less percentages of islets and ducts as interfering cells. The acinar cells were suspended in Hams F-12 with $10 \%$ FBS and maintained $\left(37^{\circ} \mathrm{C}\right.$ temperature and $95 \%$ humidity in $5 \% \mathrm{CO}_{2}$ ) for a period of $24 \mathrm{hr}$. These cells were checked for viability and were characterized for the protein expression and functional assays.

\section{Experimental design}

The primary acinar cells isolated from pancreas of 3 months old WNIN male rats were maintained in Hams F12 with 10\% FBS for 24 hours. These cells were divided in to 4 groups; Cells in group1 were maintained in Hams F12 with 10\% FBS and were considered as control, Group 2 cells were similar to group 1, but were treated with $100 \mu \mathrm{M} \mathrm{H}_{2} \mathrm{O}_{2}$ for 30 min and considered as $\mathrm{H}_{2} \mathrm{O}_{2}$ treated group, Group 3 cells were treated with $5 \mathrm{mM}$ PLP and considered as PLP treated group while Group 4 cells were similar to group 3, but had a post treatment with $100 \mu \mathrm{M} \mathrm{H}_{2} \mathrm{O}_{2}$ for a period of 30 minutes and considered as PLP with $\mathrm{H}_{2} \mathrm{O}_{2}$ group.

\section{Viability assay}

Cell viability was assessed by 3-(4,5-dimethylthiazol-2-yl)-2,5-diphenyl tetrazolium bromide (MTT) assay [31]. Briefly, acinar cells ( 1 X $\left.10^{5}\right)$ were collected and incubated with PLP (5 mM) for $24 \mathrm{~h}$ and viability was measured by uptake of MTT reagent wavelength at $532 \mathrm{~nm}$ of all groups.

\section{FACS Analysis}

The percentage of amylase (dilution: 1in 200), insulin (dilution: 1in 200), PDX-1(dilution: 1in 100), Neurogenin-3 (dilution: 1in 100) expressions were computed from treated and untreated cells by FACS analysis. Briefly; cells (1X106) fixed with $70 \%$ chilled ethanol for $2 \mathrm{~h}$ at $-20^{\circ} \mathrm{C}$ and washed with 1X PBS solution was followed by permiabilization with $0.05 \%$ Triton 100X and $0.001 \%$ Tween20 solution. Cells were incubated with $2 \%$ BSA in PBS solution for $30 \mathrm{~min}$ for reducing the background, followed by primary antibody for $1 \mathrm{~h}$ and washed with 1X PBS and followed by secondary antibody for $1 \mathrm{~h}$. The percentages of proteins were analysed by FACS Diva software (FACS Aria II, BD,CA).

\section{Measurement of oxidative stress}

$1 \times 10^{5}$ acinar cells were taken to measure cellular ROS using dichloro fluorescein diacetate (DCFDA) at an excitation wavelength of $485 \mathrm{~nm}$ and emission at a wavelength of $535 \mathrm{~nm}$ in all the groups by enzyme linked immune sorbent assay (ELISA) [32]. The values were expressed in relative fluorescence units (RFU).

\section{Immunohistochemistry}

Immuno histochemistry experiment was performed for isolated acinar cells with and without PLP treatments using cytospin sections (cytospin machine at $1000 \mathrm{rpm}$ for 3 minutes (slight 
modification) of the acinar cells. Briefly, $2 \times 10^{3}$ cells were fixed with $4 \%$ paraformaldehyde, washed with 1X PBS permeabilized with $0.05 \%$ triton 100X with $0.001 \%$ tween-20 solution for 6 min, and blocked with 2\% BSA solution. Further cells were incubated with primary antibody amylase (1: 200 dilutions) for $1 \mathrm{~h}$ followed by secondary antibody anti-rabbit FITC (1: 200). Cytospin sections were mounted with DAPI containing medium which stains nuclei of cells. The images were captured by using confocal microscopy (Leica, SP5 series, Germany).

\section{Insulin secretion assay}

Insulin secretion assay (ISA) was performed as per the earlier reported method (Kiran et al., 2011) [17]. Briefly, acinar cells $\left(1 \times 10^{5}\right)$ were subjected to insulin secretion at basal $(5.5 \mathrm{mmol} / \mathrm{L})$ followed by high glucose challenge $(16.5 \mathrm{mmol} / \mathrm{L})$ in Krebs Ringer Bicarbonate (KRB) buffer. Insulin secreted into the buffer was estimated using High Range Rat Insulin ELISA Kit (Mercodia, Sweden) and values were represented as $\mu \mathrm{U} / \mathrm{L}$ insulin/mg protein.

\section{Statistical analyses}

Descriptive statistics (Mean, SE) were calculated for all the samples. To compare between the group analysis of variance (ANOVA) followed by post hoc tests (LSD/Dunnett's C test) were carried out based on Levene's test for equality of error variances. Data were expressed as mean \pm SE computed from experiments performed in triplicates per group. $\mathrm{p}<0.05$ was considered significant for all the tests. All the statistical analyses were performed using Graph pad prism 5.

\section{Results}

\section{Morphology of acinar cells}

Isolated acinar cells maintained under culture conditions with $5 \mathrm{mM}$ PLP (Fig. 1C) showed cell morphology with intact boundaries. Unlike those with $100 \mu \mathrm{M} \mathrm{H} \mathrm{H}_{2}$ treatment for 30 minutes, which showed slight disintegration of morphology (Fig.1B) the control cells (Fig. 1A) or cells with PLP treatment (Fig.1 B) which showed cells with intact boundaries. The cells maintained in $5 \mathrm{mM}$ PLP for 23.5 hours and $100 \mu \mathrm{M} \mathrm{H}_{2} \mathrm{O}_{2}$ treatment for 30 minutes before collection showed normal cell integrity.

Figure 1 Figure shows freshly isolated acinar cells from 3month old WNIN male rats were maintained in Hams F-12 medium containing 10\% FBS with and without PLP for 24 hours. Acinar cells maintained in normal medium containing Ham's F-12 with 10\% FBS in group 1(A). Acinar cells maintained in medium containing Ham's F-12 with 10\% FBS before collecting cells treated with $100 \mu \mathrm{M} \mathrm{H}_{2} \mathrm{O}_{2}$ for 30 minutes in group 2. The cells were Ham's F-12 medium with $10 \%$ FBS along with 5mM PLP (C) and in Hams F12 with 10\%FBS and 5mM PLP before collecting cells were treated with $100 \mu \mathrm{M} \mathrm{H} \mathrm{H}_{2}$ for 30 minutes in group 4 (D). Phase contrast light microscopy magnifications were captured with 20X magnifications.

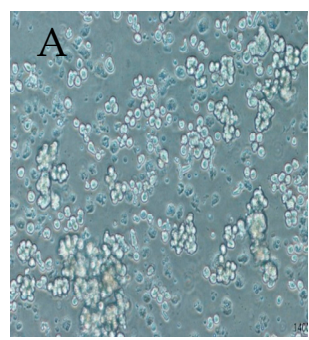

UT

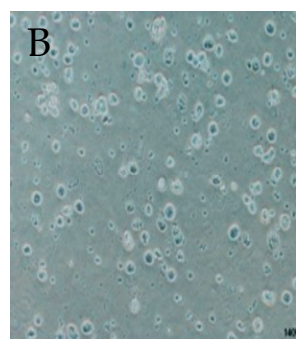

$100 \mu \mathrm{M} \mathrm{H}_{2} \mathrm{O}$

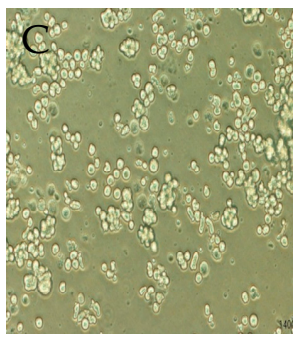

$5 \mathrm{mM}$ PLP

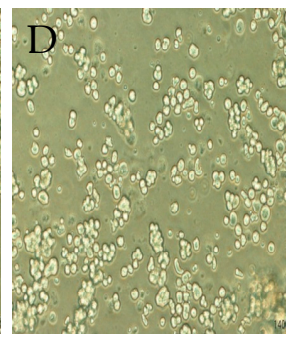

$5 \mathrm{mM} \mathrm{PLP}+100 \mu \mathrm{M} \mathrm{H}_{2} \mathrm{O}_{2}$

\section{Cell viability}

Viability assay of the acinar cells showed $82 \%$ viability in group 2 (only $\mathrm{H}_{2} \mathrm{O}_{2}$ ), 99\% in group 3 (PLP) and group $4\left(\mathrm{PLP}+\mathrm{H}_{2} \mathrm{O}_{2}\right)$ with respect to group 1 which was considered as $100 \%$ control (Figure 2). 
Figure 2 Viability Assay. Isolated primary acinar cells from 3 month old male WNIN rats were maintained in Hams F-12 with 10\% FBS contained medium. Viability of cells showed in percentage, first lane cells of group1, second lane $100 \mu \mathrm{M}$ of $\mathrm{H}_{2} \mathrm{O}_{2}$ for 30 minutes were in group2, followed, third lane 5mM PLP was group 3and fourth lane $5 \mathrm{mM}$ PLP and $100 \mu \mathrm{M}$ of $\mathrm{H}_{2} \mathrm{O}_{2}$ prior collection of cells were in group4.

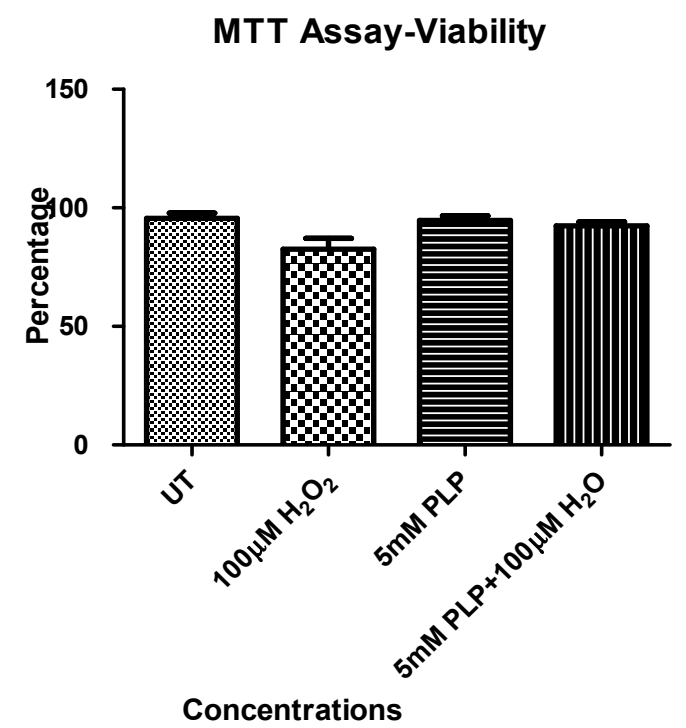

\section{Effects of $\mathrm{H}_{2} \mathrm{O}_{2}$ induced ROS}

$\mathrm{H}_{2} \mathrm{O}_{2}$ is known to induce oxidative stress. Here, we have used $100 \mu \mathrm{M} \mathrm{H} \mathrm{O}_{2}$ treatments for 30 min to induce the ROS. This ROS assay was performed and comparative ROS levels were measured as arbitrary values in all groups. Among all groups average values were group1 (4060), group 2 (4140), group 3 (5930) and group 4 (4170) after $24 \mathrm{~h}$ treatment (Figure 3).

Figure 3 ROS Assay for measurement of antioxidant activity. Isolated primary acinar cells from three month old WNIN male rat were maintained with Hams F-12 with 10\% FBS contained medium. First lane cells represents group1, followed second lane showed $100 \mu \mathrm{M}$ of $\mathrm{H}_{2} \mathrm{O}_{2}$ treatment for 30 minutes in group 2. The third lane showed 5mM PLP of group 3 and fourth lane was $5 \mathrm{mM}$ PLP and $100 \mu \mathrm{M}$ of $\mathrm{H}_{2} \mathrm{O}_{2}$ for 30 minutes in group4.

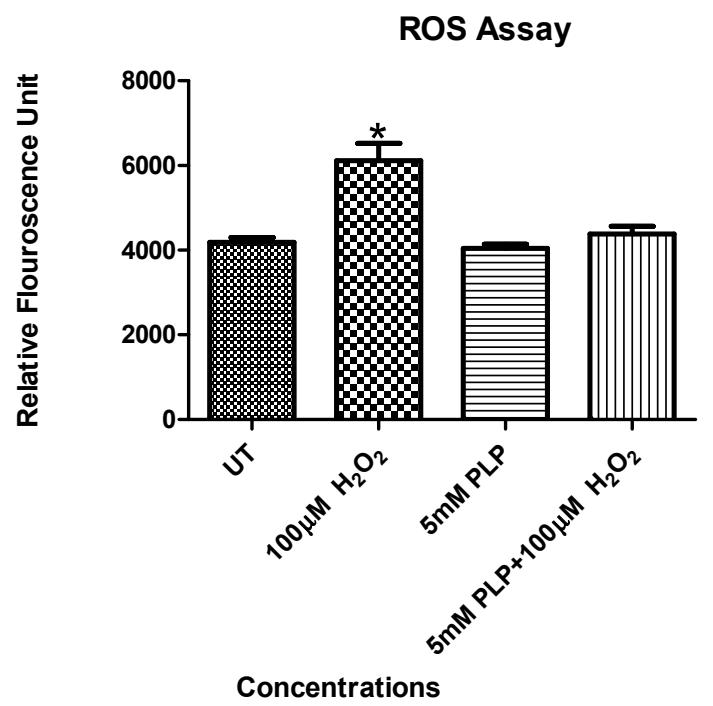




\section{Demonstration of amylase protein expression in acinar cells}

Acinar cells are rich in amylase protein expression, which is useful for the digestive property of the tissue. Here, we had checked the impact of oxidative stress induced by $100 \mu \mathrm{M} \mathrm{H}_{2} \mathrm{O}_{2}$ on acinar cells in vitro. Data in Figure 4A represents that amylase expression was decreased by $\mathbf{2 . 2 0}$ fold in group3 compared with group1 (control). Further amylase protein expression was decreased by $\mathbf{2 . 2 0}$ folds upon treatment with $\mathrm{H}_{2} \mathrm{O}_{2}$ (group 2) to group1 cells, but presence of PLP had increased the expression by $\mathbf{2 . 2 0}$ folds and in cells pre-treated with PLP (group4) no effect was observed upon $\mathrm{H}_{2} \mathrm{O}_{2}$ treatment (Figure 4A). The specificity of PLP in amylase protein expression was negated with its specific inhibitor (AOAA) (Figure 4B), where amylase localization was increased significantly in group3 cells as observed with confocal microscopy (Figure 4C). Why so many 2.20 folds

Figure 4 FACS analysis of amylase protein percentage expression in acinar cells, were islated from 3 months old male WNIN rats. A) The histograms represents of first was normal of group 1fallowed second was by $100 \mu \mathrm{M}$ of $\mathrm{H}_{2} \mathrm{O}_{2}$ in group 2, then third was 5mM PLP treatment of group 3. Followed fourth was $5 \mathrm{mM}$ PLP with $100 \mu \mathrm{M}$ of $\mathrm{H}_{2} \mathrm{O}_{2}$ treatment for 30 minutes in group4. B) The histograms represents of first was normal of group1 followed 5mM PLP of gropu 3 with PLP inhibitor AOAA. C) Immunohistochemistry of amylase protein expression in acinar cells by confocal microscopy. Upper panel represents untreated cells of group1 and lower panel showed $5 \mathrm{mM}$ PLP treatment of group 3. First lane showed phase contrast, middle lanes shows nucleus staining of DAPI and last panel showed amylase protein expressions.

\section{Figure 4.}

A) Amylase

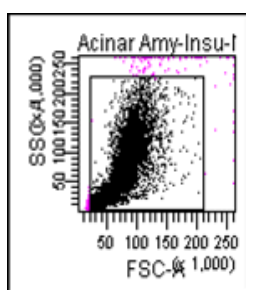

All Events

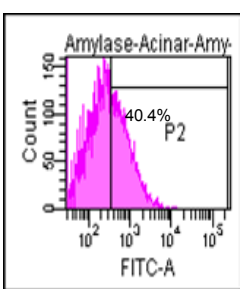

UT

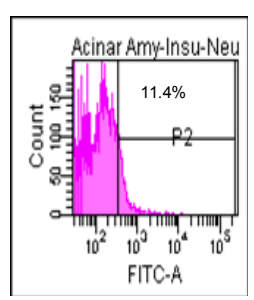

$100 \mu \mathrm{M} \mathrm{H}_{2} \mathrm{O}$

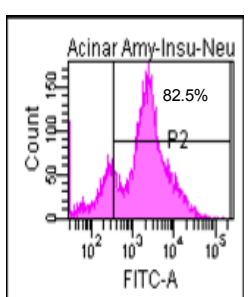

$5 \mathrm{mM}$ PLP

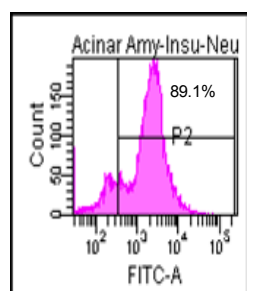

$5 \mathrm{mM} \mathrm{PLP}+100 \mu \mathrm{M} \mathrm{H}_{2} \mathrm{O}_{2}$

B) Amylase with PLP inhibitor AOAA

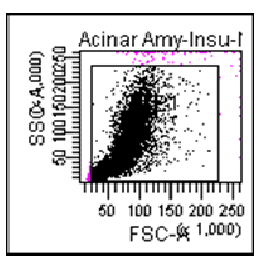

All Events

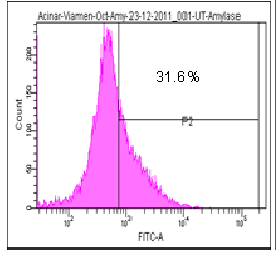

UT

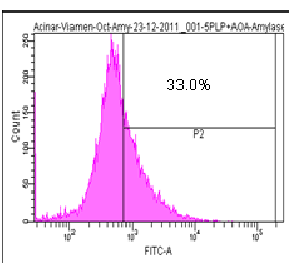

$5 \mathrm{mM}$ PLP+AOAA 
4A) Amylase

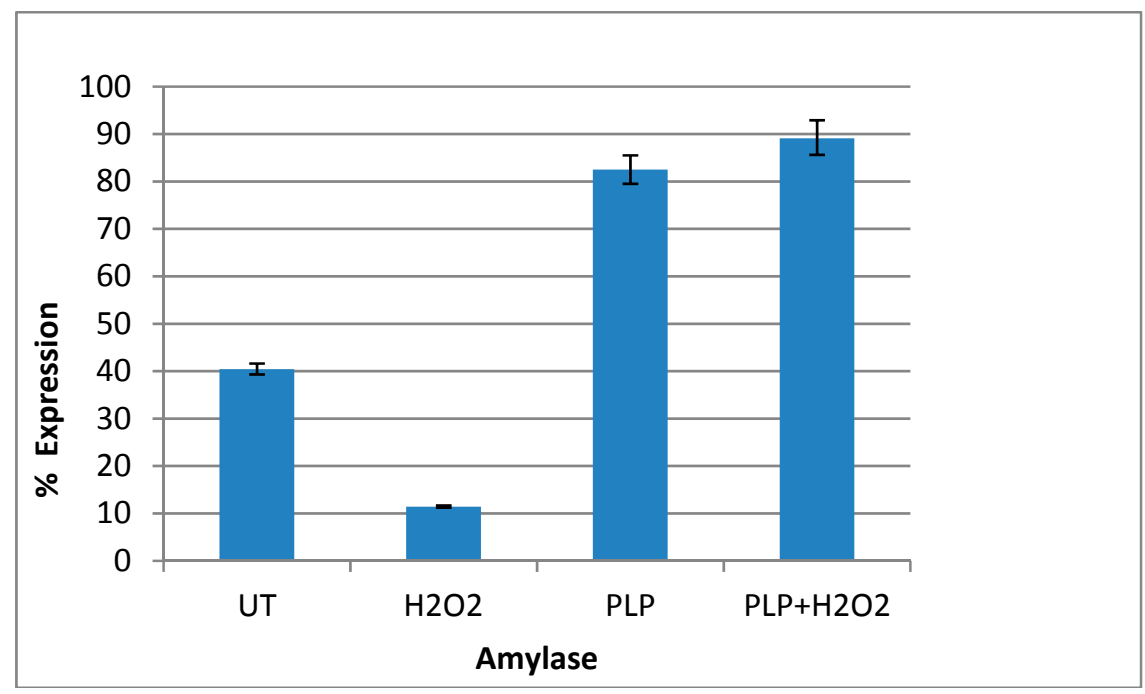

4B) Amylase with PLP inhibitor AOAA

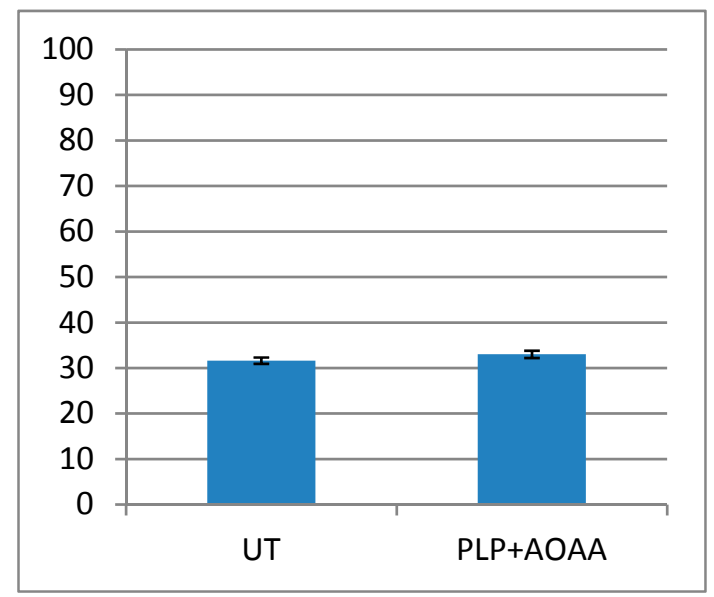

4C)
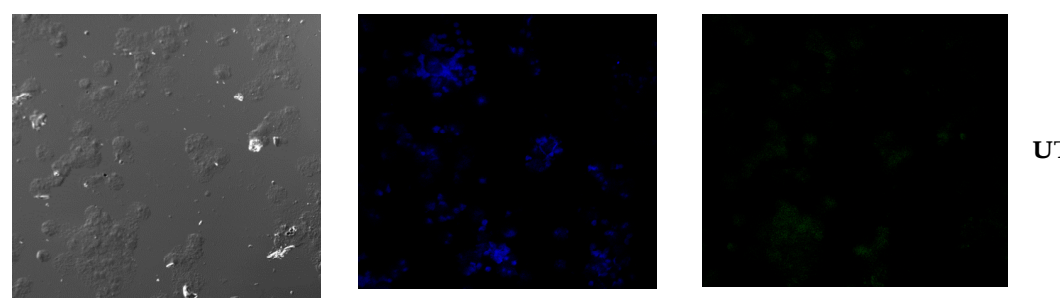

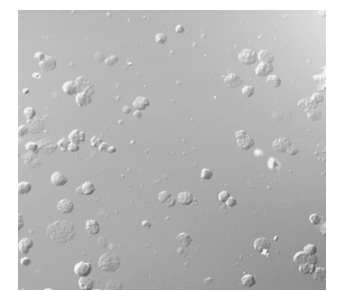

Phase

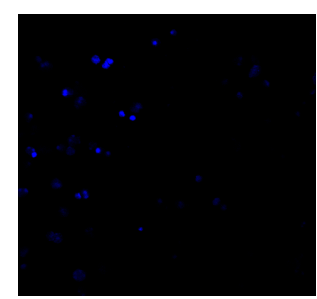

DAPI

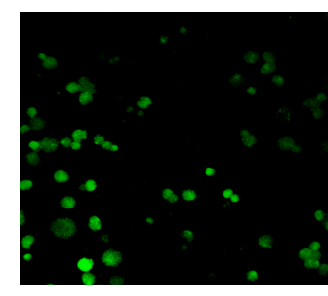

Amylase
UT

5mM PLP

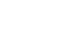




\section{FACS analysis of Ngn3, PDX-1 and insulin proteins}

The pancreatic transcription factor Ngn3 expression was increased by 9.4 folds in PLP (group3), and $\mathrm{H}_{2} \mathrm{O}_{2}$ treatment was slightly increased 1.51 folds (group2) as well as group4 was increased 5.6 folds (Figure 5A). In similar way another transcription factor PDX-1 expression was increased 23.6 folds in PLP treated cells (group3), and $\mathrm{H}_{2} \mathrm{O}_{2}$ treatment has slightly increased to 1.13 folds (group2), but group4 was increased 25.82 folds (Figure 5B). Another protein insulin expression was increased 13.58 folds PLP treatment (group3), and $\mathrm{H}_{2} \mathrm{O}_{2}$ treatment was slightly increased 1.58 folds (group2) and group4 was decreased 4.26 folds (Figure 5C).

Figure 5 FACS analysis percentage representations of different protein expressions in acinar cells. The first histogram represent untreated cells (Group1) fallowed by $100 \mu \mathrm{M}$ of $\mathrm{H}_{2} \mathrm{O}_{2}$ (Group2), $5 \mathrm{mMPLP}$ (Group3) and 5mM PLP with $100 \mu \mathrm{M}$ of $\mathrm{H}_{2} \mathrm{O}_{2}$ treatments for $30 \mathrm{~min}$ (Group 4). The corresponding proteins were represented histograms of 5A) Neurogenin-3, 5B) PDX-1, 5C) Insulin.

A) Neurogenin-3
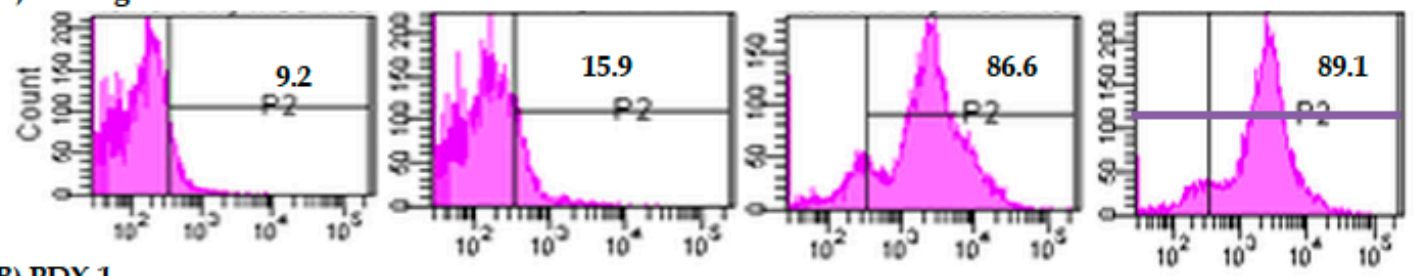

B) PDX-1
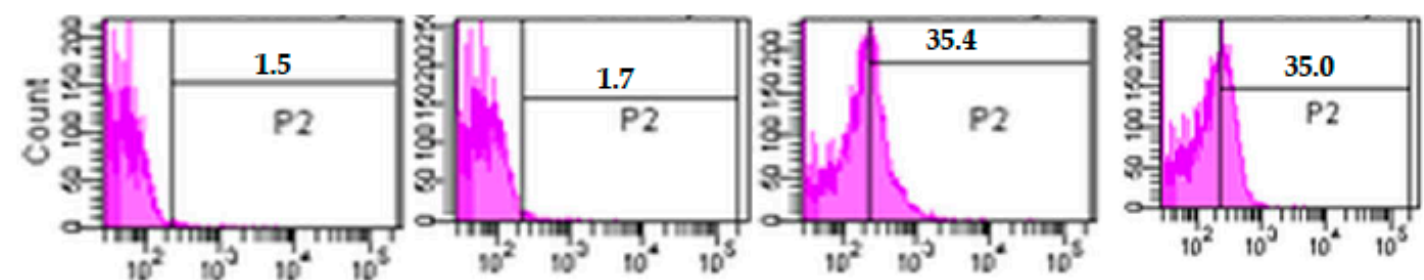

C) Insulin
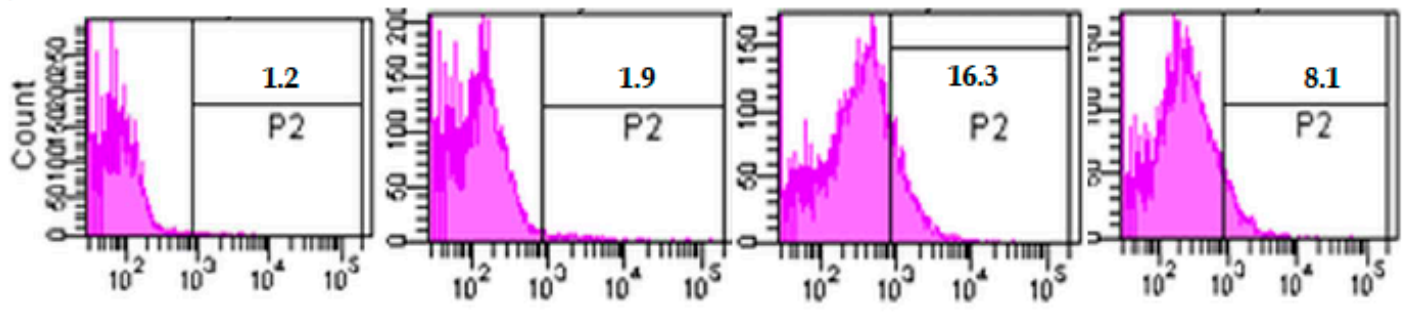

UT

$100 \mu \mathrm{M} \mathrm{H}_{2} \mathrm{O}_{2}$

$5 \mathrm{mM}$ PLP

$5 \mathrm{mM}$ PLP $+100 \mu \mathrm{M} \mathrm{H}_{2} \mathrm{O}_{2}$

5A) Neurogenin-3

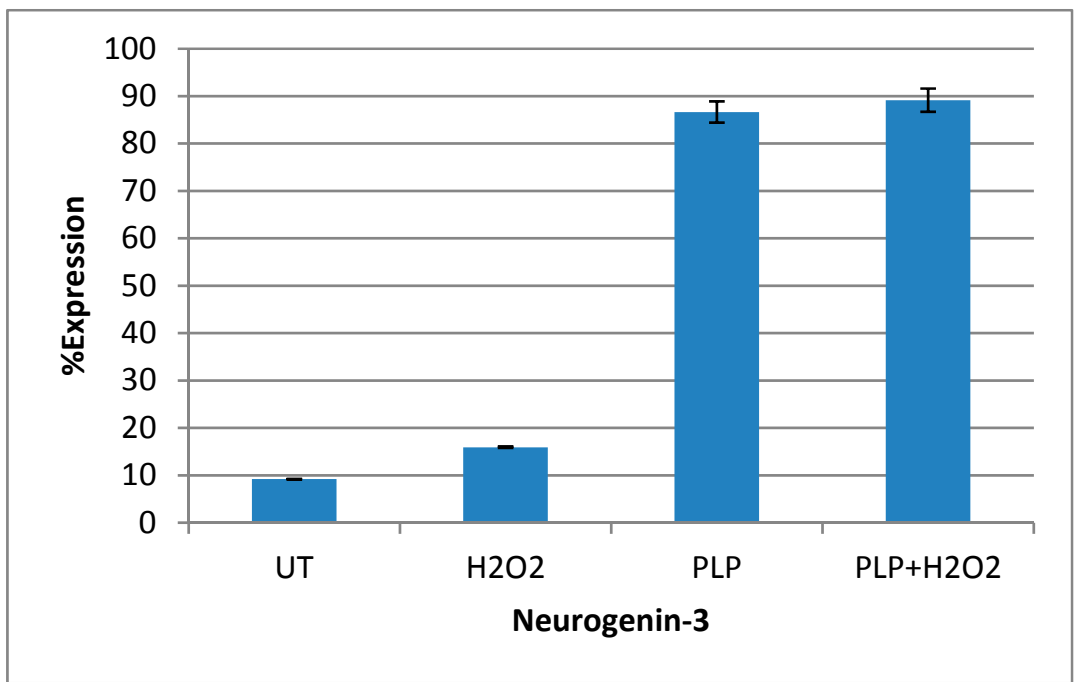


5B) PDX-1

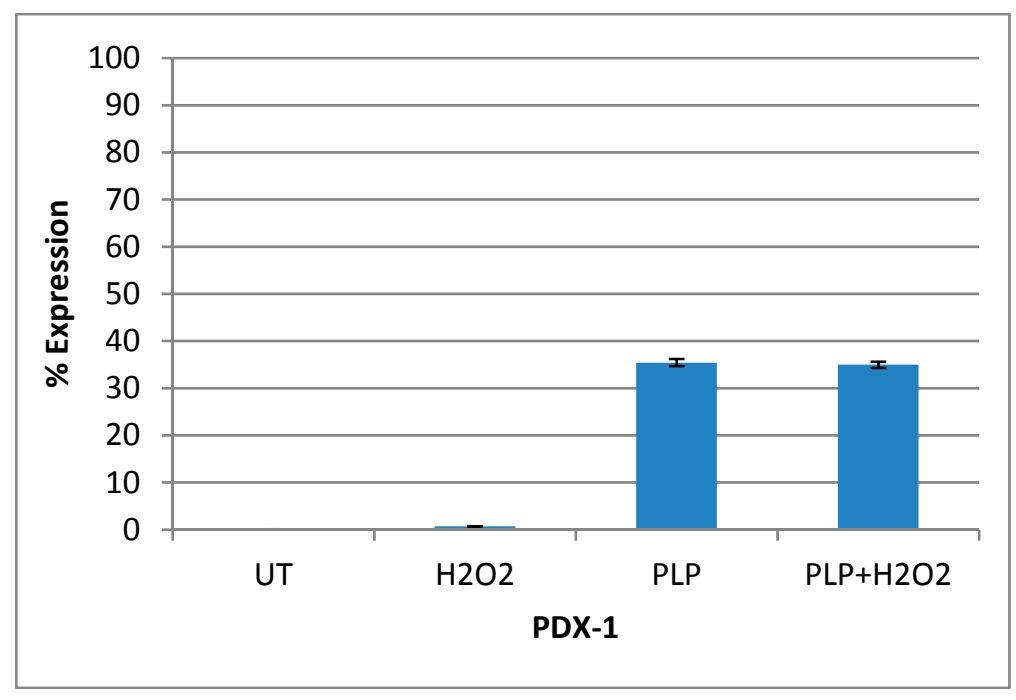

5C) Insulin

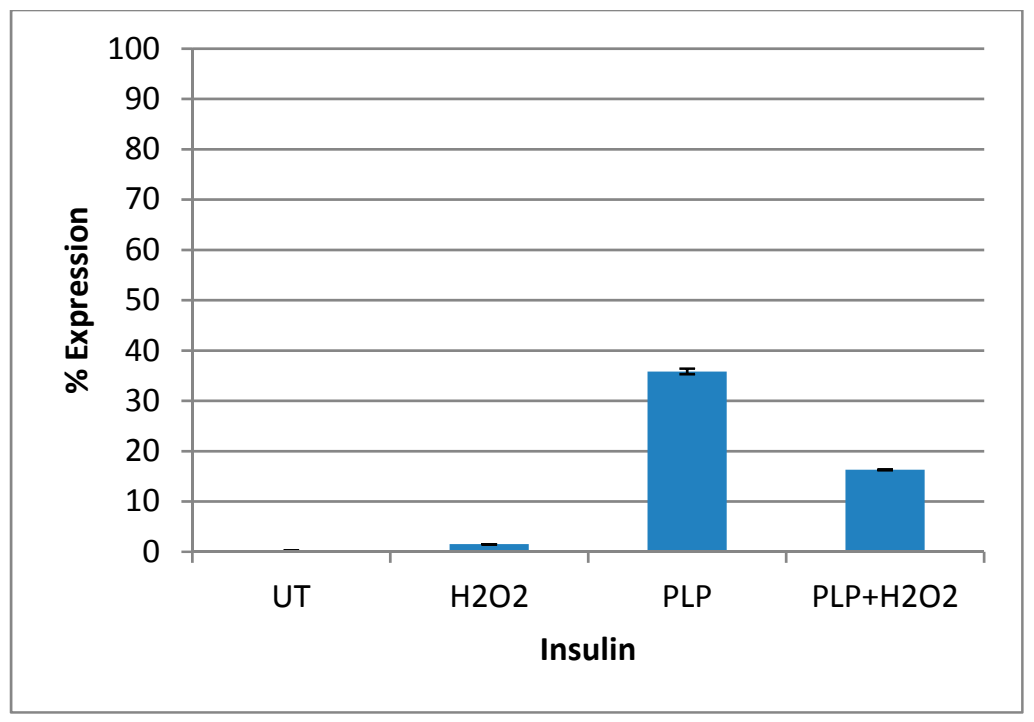

\section{Insulin secretion assay}

Table.1 shows the insulin secretion assay carried out in primary acinar cell cultures for all the four groups. Insulin secretion in group3 has increased by 7.13 folds at basal $(5.5 \mathrm{mmol} / \mathrm{L})$ and by 24.57 folds at stimulated $(16.5 \mathrm{mmol} / \mathrm{L})$ condition. However, in group4 cells the increase was only 2.34 folds at basal $(5.5 \mathrm{mmol} / \mathrm{L})$ and 5.65 folds at stimulated $(16.5 \mathrm{mmol} / \mathrm{L})$ level was compared to group1

Table 1 Insulin secretion assay of acinar cells by ELISA method. Insulin secretion obtained from acinar cells on basal $(5.5 \mathrm{mM})$ and stimulated $(16.5 \mathrm{mM})$ glucose treatment has been represented as $\mu \mathrm{U} / \mathrm{L} / \mathrm{mg}$ protein. First line represents untreated cells (Group1), second lane represent $100 \mu \mathrm{M}$ of $\mathrm{H}_{2} \mathrm{O}_{2}$ treated cells (Group2), third lane represents 5mM PLP treated cells (Group3), fourth lane represents $5 \mathrm{mM}$ PLP with $100 \mu \mathrm{M}$ of $\mathrm{H}_{2} \mathrm{O}_{2}$ treated cells for 30 minutes (group4). 


\begin{tabular}{|c|c|c|c|}
\hline S.No & Sample & Basal ( $\mu \mathrm{U} / \mathrm{L} / \mathrm{mg}$ protein) & Stimulated $(\mu \mathrm{U} / \mathrm{L} / \mathrm{mg}$ protein $)$ \\
\hline 1. & Un Treated & $0.89 \pm 0.24$ & $0.38 \pm 0.15$ \\
\hline 2. & $100 \mu \mathrm{M} \mathrm{H} \mathrm{O}_{2}$ & $0.63 \pm 0.10$ & $0.32 \pm 0.14$ \\
\hline 3. & 5mM PLP & $6.35 \pm 0.53$ & $9.34 \pm 0.45$ \\
\hline 4. & $5 \mathrm{mM} \mathrm{PLP}+100 \mu \mathrm{M} \mathrm{H}_{2} \mathrm{O}_{2}$ & 2. $09 \pm 0.13$ & $2.16 \pm 0.12$ \\
\hline
\end{tabular}

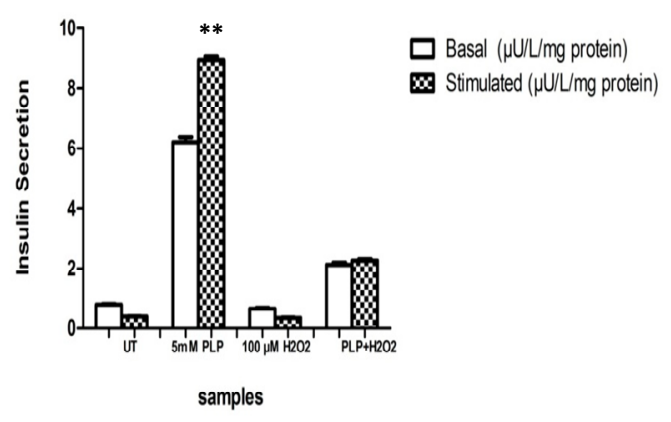

\section{Discussion}

PLP is an active form of vitamin B6, well known for its anti-oxidant activity. The published work from our group was demonstrated cytoprotective and insulinotrophic effects of PLP against STZ induced beta cell dysfunction. It further expanded $5 \mathrm{mM}$ PLP concentration was elicit the action in both in vivo and in vitro [17]. But, effect PLP on exocrine fraction of acinar cells in pancreas was not known. Our study, demonstrates for the first time, cytoprotective effect of PLP on $\mathrm{H}_{2} \mathrm{O}_{2}-$ induced OS in isolated acinar cells. It was known that OS damages mitochondria in acinar cells [33] which might be the possible mechanism of free radical injury in this cellular fraction [34]. Another study reported that $\mathrm{H}_{2} \mathrm{O}_{2}$ induces $\mathrm{OS}$, which affects the integrity of plasma membrane, cytoskeleton arrangements and cell-cell interaction, actin polymerization in rat astrocytes [29]. In similar lines, we have checked the effect of PLP on isolated acinar cells. Acinar cells are known for amylase protein expression, the maximal amylase expression was elicited with $5 \mathrm{mM}$ concentration (from the range of $0.5,1,2.5,5,10 \mathrm{mM}$ of PLP (Complete data was not presented).

This $5 \mathrm{mM}$ PLP concentration was used for all further experiments in this study for group (groups $3 \& 4$ ). Further a significant increased in the protein levels of amylase (2.20 folds) were observed in group3; where PLP was present, whereas $\mathrm{H}_{2} \mathrm{O}_{2}$ induced stress in group2 significantly reduced in amylase (3.54 folds) expression was assessed by the FACS analysis. But, PLP treated cells were cytoprotected from $\mathrm{H}_{2} \mathrm{O}_{2}$ induced damage (Fig. 4A). The increased amylase expression was with PLP's effect was confirmed by using PLP inhibitor AOAA (Fig. 4B). Further, immunohistochemical analysis experiment reiterated the significant increased amylase expression with PLP (Fig.4C). The role of oxidative stress (OS) in the pathogenesis and complications of diabetes mellitus studies were well documented $[35,36]$. ROS induced with different forms of chemical treatments; one of known agent is $\mathrm{H}_{2} \mathrm{O}_{2}$; which also acted as a signalling molecule to trigger cellular apoptotic pathways [37-41]. The different concentrations $(0-400 \mu \mathrm{M})$ range was used to induce OS in astrocyte membrane and cytoskeleton in cultured cells [29]. It also disrupts the intracellular transport of digestive enzyme, leading to their premature activation form [42]. We also observed similar way of elevated levels of ROS being induced with $\mathrm{H}_{2} \mathrm{O}_{2}$ (group2) in acinar cells, which was normalized in presence of PLP (group4) and alone PLP effect was comparable with group1 (Fig.3). The PLP treatment group3 and control group1 had same morphology; whereas the cellular morphology in group2 was slight disintegrated (Fig.1). It may be due to the induced ROS was damages the edges of the acinar cells. However, the viability of cells in culture showed no significant difference among all the four groups (Fig.2). 
Generation of $\beta$-Cells from exocrine pancreas is a novel source of new cells. It was reported that acinar cells can transdifferentiate into insulin secreting cells [43]. It was also reported that development of pancreas (exocrine/ endocrine) was regulated by a number of genes and transcription factors among which PDX-1, Ngn3 and MafA are essential for the trans-differentiation of endocrine cells. Among these, PDX-1 controls growth and development of pancreatic bud and Ngn3 was required for endocrine progenitors [44-46]. The duodenal homeobox-1 (PDX-1) was important marker has been used in development and differentiation of exocrine, endocrine and ductal epithelial cells [47]. It was expressed in the gut region of pancreas and give rise to all three types of pancreatic tissue - endocrine, exocrine and duct cells [48, 49]. Present study was expressed of this pancreatic transcription factor PDX-1 (protein) were increased by 23.6 folds in group3, but only slightly increased in group2 by 1.13 folds, while cells were in group4 showed an increase by 25.82 folds (Fig. 5B). Apart from PDX-1, neurogenin-3 another important pancreatic transcription factor plays an important role in pancreatic tissue generation, regulation and islet [21] development. It was reported that independent and synergistic effects of Pdx1, Ngn3 are observed when acinar cells are converted into $\beta$-like cells [50]. In our study, we observed a significant increased in the expressions of Ngn3 by 9.4 folds in the presence of PLP (group3) compared with untreated cells (group1) and $\mathrm{H}_{2} \mathrm{O}_{2}$ treatment had slightly increased (1.51 fold) (group2) its levels along with group4 cells (exposed with PLP followed $\mathrm{H}_{2} \mathrm{O}_{2}$ ) which had depicted an increase by 5.6 folds (Fig. 5A). These observations have proved the role of PLP in up regulation of transcription factors PDX- 1 and Ngn3 in acinar cells.

The study from type-1 diabetes animal model [28] acinar cells secrets insulin via Cre/Lox lineage tracing system in adult mice [25] was documented. We have estimated insulin protein expression levels in presence of PLP. Our observations demonstrated that PLP presence (group3) increased insulin protein expression by 13.58 folds, where as group4 was decreased 4.26 folds. Alone, $\mathrm{H}_{2} \mathrm{O}_{2}$ treatment (group2) had slightly increased 1.58 folds, but it was not significant change to compare with control (Fig.5C). In similar lines, secreted insulin levels measured with insulin secretion assay, showed a 7.13 folds increase at basal levels and 24.57 folds at stimulated in group3 cells was a significant difference. The cells in group4, where PLP treatment fallowed $\mathrm{H}_{2} \mathrm{O}_{2}$ have not showed impact by increasing of 2.34 folds at basal and 5.65 folds at stimulated conditions. Based on these observations PLP presence has undoubtedly increased insulin protein as well as secretion, but it may not completely recovered from $\mathrm{H}_{2} \mathrm{O}_{2}$ damage of insulin protein and secreted levels (Table1).

\section{Conclusions}

Taken together, the present study concludes PLP may have cytoprotective and antioxidant activity on isolated primary acinar cells; along with up regulating the amylase, insulin, Ngn3 and PDX-1 protein expression levels, also protecting from $\mathrm{H}_{2} \mathrm{O}_{2}$ induced damage.

Conflict of interest: The authors declare that there is no conflict of interest

Acknowledgements: This work was supported by Institute Intramural Grant Project Code Number: 03-BS14 from National Institute of Nutrition, Hyderabad under Indian Council of Medical Research (ICMR), Ministry of Health and Family Welfare, New Delhi.

Author contributions: AR carried out the experiments; MC gave technical support for insulin secretion assay; AR and VV planned the experiments, drafted the manuscript.

\section{References}

1. Blokhina, O.; Virolainen, E.; Fagerstedt, K,V. Antioxidants, oxidative damage and oxygen deprivation stress: a review. Ann Bot, 2003, 91, 179-194.

2. Claudia, V,P.; Shashi, N.; Paulo, J,O.; Yvonne, W. The contribution of oxidative stress to drug induced organ toxicity and its detection in vitro and in vivo. Expert Opin Drug Metab Toxicol, 2012, 8, 219-237. 
3. Emily, S. Quantification and significance of protein oxidation in biological samples. Drug Metab Rev, 2000, 32, 307-326.

4. Wyllie, A, H.; Duvall, E. Cell injury and cell death. Oxford textbook of pathology. Oxford University Press, 1992, 141-193.

5. Andre, Q.S.; Larissa, D.B.; Alexandra, L.; Moacir, W.; Diogo, O, S.; Carlos, A,G.; Carmem, G. Resveratrol protect C6 astrocyte cell line aganist hydrogen peroxide induced oxidative stress through heme oxygenase1. PLoS One, 2013, 8, e64372.

6. Christophe, J. Pancreatic tumoral cell line AR42J: an amphicrine model. Am J Physiol, 1994, 266, G963971.

7. Atli, T.; Keven, K.; Avci, A.; Kutlay, S.; Turkcapr,N.; Varli,M.; Aras, S.; Ertug, E.; Canbolar, O. Oxidative stress and antioxidant status in elderly diabetes mellitus and glucose intolerance patients. Arch Gerontol Geriatr, 2004, 39, 269-275.

8. Hellman, B.; Idahl, L,A.; Lernmark, A.; Sehlin, J.; Taljedal, I,P. The pancreatic beta-cell recognition of insulin secretagogues XIII. Effects of sulphydryl reagents on cyclic AMP. Biochim Biophys Acta, 1974, 4, 127-134.

9. Halliwell, B. Vitamin C: poison, prophylactic or panacea?. Trends Biochem Sci, 1999, 24, 255-259.

10. Buettner, G,R. The pecking order of free radicals and antioxidants: lipid peroxidation, alpha-tocopherol, and ascorbate. Arch Biochem Biophys, 1993, 300, 535-543.

11. Packer, L. Vitamin E is nature's master antioxidant. Sci Am Sci Med, 1994, 1, 54-63.

12. Aruoma, O,I.; Halliwell, B,M.; Hoey, J,B. The antioxidant action of N-acetylcysteine: its reaction with hydrogen peroxide, hydroxyl radical, superoxide, and hypochlorous acid. Free Radic Bio Med, 1989, 6, 593-597.

13. Sanbogi, C.; Osakabe, N.; Natsume, M.; Takizawa, T.; Gomi, S.; Osawa, T. Antioxidative polyphenols isolated from Theorem cocoa. J Agric Food Chem, 1998, 46, 454-457.

14. Iqbal, M.; Okazaki, Y.; Okada, S. Curcumin attenuates oxidative damage in animals treated with a renal carcinogen, ferric nitrilotriacetate (Fe-NTA): implications for cancer prevention. Mol Cell Biochem, 2009, 324, 157-164.

15. Kangralkar, V,A.; Patil, S,D.; Bandivadekar, R,M. Oxidative stress and diabetes: A review. Int J Pharmaceut Appl, 2011, 1, 38-45.

16. Hardt, P,D.; Krauss, A.; Bretz, L.; porsch, O,M.; Schnell, K,H.; Maser, E.; Bretzel, R,G.; Zekhorn, t.;Klor, $\mathrm{H}, \mathrm{U}$. Pancreatic exocrine function in patients with type 1 and type 2 diabetes mellitus. Acta Diabetol, 2000, 37, 105-110.

17. Kiran, S,G.; Dorisetty, R,K.; Umrani, M,R.; Boindala, S.; Bhonde, R,r.; Chalasani, M.; Singh, H.; Venkatesan, V. Pyridoxal 5' phosphate protects islets against streptozotocin-induced beta-cell dysfunction - in vitro and in vivo. Exp Biol Med, 2011, 236, 456-465.

18. Tambasco,S,M.; Titiz, O.; Raschle, T.; Forster, $\quad$ G.; Amrhein, $\quad$ N.; Fitzpatrick, T,B.http://www.ncbi.nlm.nih.gov/pubmed/?term=Forster\%20G\%5Bauth\%5D Vitamin B6 biosynthesis in higher plants. Proc Natl Acad Sci U S A, 2005, 102, 13687-13692.

19. Bonner, W,S.; Trent, D,F.; Weir, G,C. Partial pancreatectomy in the rat and subsequent defect in glucose induced insulin release. J Clin Invest, 1983, 71, 1544-1553.

20. Brockenbrough, J,S.; Weir, G,C,; Bonner, W,S. Discordance of exocrine and endocrine growth after 90\% pancreatectomy in rats. Diabetes, 1988, 37, 232-236.

21. Gradwohl, G.; Dierich, A.; LeMeur, M.; Guillemot, F. Neurogenin3 is required for the development of the four endocrine cell lineages of the pancreas. Proc Natl Acad Sci USA, 2000, 97, 1607-1611.

22. Bernardo, A,S.; Hay, C,W.; Docherty, K. Pancreatic transcription factors and their role in the birth, life and survival of the pancreatic beta cell. Mol Cell Endocrinol, 2008, 294,1-9.

23. Kataoka, K.; Han, S,I.; Shioda, S.; Hirai, M.; Nishizawa, M.; Handa, H. MafA is a glucose-regulated and pancreatic beta-cell-specific transcriptional activator for the insulin gene. J Biol Chem, 2002, 277, 4990349910.

24. Means AL, Meszoely IM, Suzuki K, Miyamoto, Y.; Rustgi, A, K.; Coffey, R,J, Jr.; Wright, C, v.; Stoffers, D,A.; Leach, S, D. Pancreatic epithelial plasticity mediated by acinar cell transdifferentiation and generation of nestin-positive intermediates. Development, 2005, 132, 3767-3776. 
25. Minami, K.; Okuno, M.; Miyawaki, K.; Okumachi, A.; Ishizaki, K.; Oyama, k.; Kawaguchi, M.; Ishizuka, N.; Iwanaga, T.; Seino, S. Lineage tracing and characterization of insulin-secreting cells generated from adult pancreatic acinar cells. Proc Natl Acad Sci USA, 2005, 102, 15116-15121.

26. Miyatsuka, T.; Kaneto, H.; Shiraiwa, T.; Matsuoka, T,A.; Yamamoto, K.; Kato, K.; Nakamura, Y,; Akira, S.; Takeda, K.; Kajimoto, Y.; Yamasaki, Y.; Sandgren, E,P.; Kawaguchi, Y.; Wright, C,V.; Fujitani, Y. Persistent expression of PDX-1 in the pancreas causes acinar-to-ductal metaplasia through Stat3 activation. Genes Dev, 2006, 20, 1435-1440.

27. Baeyens, L.; De Breuck, S.; Lardon, J.; Mfopou, J,K.; Rooman, I.; Bouwens, L. In vitro generation of insulin-producing beta cells from adult exocrine pancreatic cells. Diabetologia, 2005, 48, 49-57.

28. Okuno, M.; Minami, K.; Okumachi, A.; Miyawaki, K.; Yokoi, N.; Toyokuni, S.; Seino, S. Generation of insulin-secreting cells from pancreatic acinar cells of animal models of type 1 diabetes. Am J Physiol Endocrinol Metab, 2007, 292, 158-165.

29. Donghui, Z.; Kevin, S, T.; Xiaolin, Z.; Sun, A,Y.; Sun, G,Y.; Lee, J,C. Hydrogen peroxide alters membrane and cytoskeleton properties and increases intercellular connections in Astrocytes. J Cell Sci, 2005, 118, 3695-3703.

30. Husain, S,Z.; Prasad, P.; Grant, W, M.; Kolodecik, T, R.; Nathanson, M,H.;gorelick, F, S. The ryanodine receptor mediates early zymogen activation in pancreatitis. Proc Natl Acad Sci USA, 2005, 102, 1438614391.

31. Vijayalakshmi, V.; Naseem, B.; Khan, A, A.; Capoor A,K.; Habibullah, C,M. Comparison of biochemical and cytotoxic functions of hepatocytes from goat, pig and human fetuses. J Gastroenterol Hepatol, 2004, 19, 1029-1035.

32. Ardestani, A.; Yazdanparast, R.; Nejad, A,S. 2-Deoxy-D-ribose-induced oxidative stress causes apoptosis in human monocytic cells: prevention by pyridoxal-5'phosphate. Toxicol In Vitro, 2008, 22, 968 -979 .

33. Ehlers, R,A.; Hernandez, A.; Bloemendal, L,S.; Ethridge, R,T.; Farrow, B.; Evers, B,M. Mitochondrial DNA damage and altered membrane potential (delta psi) in pancreatic acinar cells induced by reactive oxygen species. Surgery, 1999, 126, 148-155.

34. Jungermann, J.; Lerch, M, M.; Weidenbach, H.; Lutz, M,P.;Kruger, B.; Adler, G. Disassembly of rat pancreatic acinar cell cytoskeleton during supramaximal secretagogue stimulation. Am J Physiol, 1995, 268, G328-338.

35. Nakamura, S.; Li, H.; Adijiang, A.; Pischetsrieder, M.; Niwa, T. Pyridoxal phosphate prevents progression of diabetic nephropathy. Nephrol Dial Transplant, 2007, 22, 2165-2174.

36. Stitt, A.; Gardiner, T,A.; Alderson, N,L.; Canning, P.; Frizzell, N.; Duffy, N.; Boyle, C.; Januszewski, A,S.; Chachich, M.; Baynes, J,W.; Thorpe, S,R. The AGE inhibitor pyridoxamine inhibits development of retinopathy in experimental diabetes. Diabetes, 2002, 51, 2826-2832.

37. Butterfield, D,A.; Lauderback, C,M. Lipid peroxidation and protein oxidation in Alzheimer's disease brain: potential causes and consequences involving amyloid beta-peptide-associated free radical oxidative stress. Free Radic Biol Med, 2002, 32, 1050-1060.

38. Howe, C,J.; Lahair, M,M.; McCubrey, J,A.; Franclin, R,A. Redox regulation of the Calcium/calmodulin dependent protein. J Biol Chem, 2004, 279, 44573-44581.

39. Huang, X.; Moir, R,D.; Tanzi, R,E.; Bush, A,I.; Rogers, J, T. Redox-active metals, oxidative stress, and Alzheimer's disease pathology. Annl N Y Acadc Sci, 2004, 1012, 153-163.

40. Lin, H,J.; Wang, X.; Shaffer, K,M.; Sasaki, C,Y.; Ma, W. Characterization of H2O2-induced acute apoptosis in cultured neural stem/progenitor cells. FEBS Lett, 2004, 570, 102-106.

41. Shin, S,Y.; Kim, C,G.; Jho, E,H.; Rho, M,S.; Kim,Y,S.; kim,Y, H.; Lee, Y,H. Hydrogen peroxide negatively modulates Wnt signaling through down regulation of $\beta$-catenin. Cancer Letter, 2004, 212, 225-231.

42. Dabrowski, A.; Konturek, S,J.; Konturek, J,W.; Gabryelewicz, A. Role of oxidative stress in the pathogenesis of caerulein induced acute pancreatitis. Eur J Phormacol, 1999, 377, 1-11.

43. Marjorie, F.; Valéry, G.; Coralie, S.; Ginette, R.; Marlène, D.; Bruno, L.; Julie, K,C.; Etienne, Hollande. Evidence for Epithelial-Mesenchymal Transition in Adult Human Pancreatic Exocrine Cells. J Histochem Cytochem, 2010, 58, 807-823.

44. Edlund, H. Pancreatic organogenesis-Developmental mechanisms and implications for therapy. Nat Rev Genet, 2002, 3, 524-532. 
45. Schwitzgebel, V,M.; Scheel, D,W.; Conners, J,R.; Kalamaras, J.; Lee, J,E.; Anderson, D,J.; Sussel, L.; Johnson, J,D.; German, M,S. Expression of neurogenin3 reveals an islet cell precursor population in the pancreas. Development, 2000, 127, 3533-3542.

46. Murtaugh, L,C.; Stanger, B,Z.; Kwan, K,M.; Melton, D,A. Melton Notch signalling controls multiple steps of pancreatic differentiation. Proc Natl Acad Sci U S A, 2003, 25, 14920-14925.

47. Hongxiang, H.; Riccardo, P. Pancreas duodenum homeobox-1 regulates pancreas development during embryogenesis and islet cell function in adulthood. Eur J Endocrinol, 2002, 146, 129-141.

48. Guz, Y.; Montminy, M,R.; Stein, R.; Leonard, J.; Gamer, L,W.; Wright, C,V.; Teitelman, G. Expression of murine STF-1, a putative insulin gene transcription factor, in beta cells of pancreas, duodenal epithelium and pancreatic exocrine and endocrine progenitors during ontogeny. Development, 1995, 121, 11-18.

49. Gu, G.; Dubauskaite, J.; Melton, D,A. Direct evidence for the pancreatic lineage: NGN3+ cells are islet progenitors and are distinct from duct progenitors. Development, 2002, 129, 2447-2457.

50. Zhou, Q.; Brown, J.; Kanarek, A.; Rajagopal, J.; Melton, D,A. In vivo reprogramming of adult pancreatic exocrine cells to beta-cells. Nature, 2008, 455, 627-632.

(C) 2016 by the authors; licensee Preprints, Basel, Switzerland. This article is an open access article distributed under the terms and conditions of the Creative Commons by Attribution (CC-BY) license (http://creativecommons.org/licenses/by/4.0/). 